20

\title{
OLD ROUTES, NEW RULES
}

\section{Smuggling rice in the porous borders of the Sulu, Celebes, and South China Sea}

\author{
Eddie L. Quitoriano
}

\section{Introduction}

This chapter explains the persistent smuggling of rice in Southeast Asia despite continued efforts to strengthen regulation and cross-country cooperation in monitoring and policing the porous borders of the region, especially those in the Sulu and Celebes Seas. ${ }^{1}$

Rice exchanges in the region preceded the creation of international borders and the formation of modern states. It formed part of the economies of the Sulu Zone that divided the Philippines and Malaysia and the Malacca Strait that divided Indonesia from Singapore and Malaysia before the Dutch, British and Spanish colonizers began to impose controls on the movement of people and goods (Saleeby, 1908; Trocki, 1979, 1990; Warren, 1977).

The historical background and the geographical connections among trading posts in the region partly explain why the unregulated trade in rice and other food products persisted even after the end of World War II when the modern states of Indonesia, Philippines and Malaysia were formed and trade pacts were inked and national laws on tariffs and customs were enacted. However, this explanation is not enough.

The chapter will show why rice smuggling continues to possess traction across the various entrepots in the region because of at least two important factors.

One, rice is the staple food in the region and is therefore an important barometer of food security. A severe fluctuation in prices caused by sudden shifts in supply or perceptions of scarcity is a source of instability and pressure that induces governments to consider all means necessary to procure rice. The stability of supply and price of this staple food, or the lack of it can fuel popular unrest, including rioting and targeted attacks against certain ethnic groups who are perceived to be hoarding supplies or involved in price gouging. As a barometer of food security, rice access also becomes a potent signifier of political legitimacy and authority of the State in countries such as the Philippines, Malaysia, and Indonesia

Two, the unregulated trade and exchange in rice is a socially embedded economic practice that has persisted for generations across the South China Sea despite the precariousness of supplies and the presence of highly protected markets.

Rice smuggling is shrouded by references to the longstanding practice of "barter trade," and there are deep social ties (ethnicity, religion, or otherwise) that bind certain groups and identities across the region. These ties were fostered by a vibrant and robust trade that existed 
long before modern states were formed and continues to exist as one of the few surviving historical relics of the trade in food and other prestige goods among East, Southeast, and South Asia.

The study demonstrates how the smuggling of rice is a strategic tool in ensuring food security and political legitimacy that often compels state and society to engage in actions that place them in alternating positions of cooperation and contestation. For example, states and substates in the region will agree to leverage and prioritize the stopping of terrorist contagion or the illegal trade in narcotic drugs and weapons rather than impose hard rules on the trade of food commodities, such as rice, and other non-lethal goods.

A nuanced approach is needed at the outset when describing rice trading and the people involved in it. The discourse on rice smuggling often paints informal cross-border trade as a site of illicit, illegal, underground, and criminal entrepreneurs (Donnan \& Wilson, 1999 ${ }^{2}$; Bonnier \& Bonnier, 2019 ${ }^{3}$; Centeno \& Portes, 2006 ${ }^{4}$. In many ports where rice is shipped or traded, however, the absence or non-payment of formal duties or taxes is more commonplace than one would expect.

These realities explain why the research looked at rice smuggling from the perspective of those directly involved in it - unearthing the distinct incentives and colorful narratives that lie beneath the often dour and dark explanations used to explain many shadow economies.

This chapter used an institutional and economic sociological approach to explore and examine the formal and informal rule systems and social relationships that surround the trade in rice. It showed how rice smuggling is an "instituted economy," or an economy embedded in social relations, where market prices do not constitute the sole determinant of the commodity's production, consumption, and exchange processes (Polanyi, 1944/1957: 60). The notion that smuggling is merely a disruption of reigning institutions or rule-systems ignores the many political, social, and cultural aspects that shape and are shaped by rice markets in Southeast Asia.

We begin with an assessment of an historically vibrant trade in rice across Southeast Asia, sourced from records and narratives of cross-border trade and the associated benefits, risks, and conflicts surrounding rice smuggling. A case study of cross-border trade between the provinces of Tawi-Tawi, Philippines and Sabah, Malaysia across the Sulu Sea is employed to train the spotlight on the impervious norms and practices that continue to shape the smuggling of food commodities such as rice across regional borders.

The study utilized "trialogues" and in-depth interviews with both formal and shadow authorities, together with scoping visits to various trading posts in the Sulu Sea. ${ }^{5}$ Empirical data is also drawn from extended conversations with consumers, traders, seafarers, financiers, local government officials and political elites, policemen and former rebels.

Finally, the author went on maritime scoping visits to numerous ports on a kumpit vessel starting from Zamboanga and going to Sulu, Tawi-Tawi and finally Sabah and back, to observe both legal and illegal cross-border activities. ${ }^{6}$ These voyages provided the rich and graphic evidence that showed the impervious multi-layered exchanges and ties that stretched across the Muslim-dominated and rice-consuming entrepots of the Philippines, Malaysia, and Indonesia in Southeast Asia.

\section{Rice security as food security and political legitimacy}

Scarcities and price spikes promote images of hunger and impoverishment that put into question the government's right to rule. States and societies have been in turmoil every time rice prices spike and domestic supplies dip. The African food riots in 2008 (affecting Mozambique, Egypt and Morocco) were a result of the 2007-2008 international rice price crisis 
(Omar et al., 2019). The 1997-1998 food riots in Indonesia were a result of the decline in supply of rice (and soybeans) and debilitating impact of the financial crisis (Mukherjee and Koren, 2019). So too were the large-scale riots in Pakistan in 1986, 2001, 2002 and 2007 (ibid.).

In all these riots, food insecurity became a clarion call to question and resist the incumbent states' right to rule. Governments would respond by quickly distributing reserves if these were available or by hastily importing rice. Sometimes the government would turn violent and find a scapegoat for the miseries facing their population.

In 1998, the Suharto regime tried to deflect blame by scapegoating and helping fan Muslim hatred against the ethnic Chinese. He ultimately failed and fell, but not before instigating bloody attacks and reprisals against ethnic Chinese traders (Indonesia Alert, February 18, 1998). ${ }^{7}$ In Pakistan, the Zia-ul-Haq and Musharraf regimes responded with killings and arrests that rallied citizens to the opposition. ${ }^{8}$ In the Philippines, the price of rice has been found to be a significant determinant in presidential election results since the $1950 \mathrm{~s}$ and well into the 2000s, and has led to the ejection of top government officials who were at the helm of agricultural bureaucracies when a rice crisis struck (Intal and Garcia, 2008).

In sum, governments are fearful of the potential tensions and violent flashpoints that may occur if access to rice is hampered by supply shortages and the consequent spikes in prices. This dilemma underscores why the smuggling of rice may be considered politically feasible and expedient if a tightening of supplies emerges.

\section{The dynamics of rice supply and smuggling behavior}

Underlying the rhetoric of globalization and a borderless world are tensions and conflicts derived from the rigidity of political borders despite the dynamism of economic cooperation and social interdependence, especially in staple food products such as rice that projects food security across the region. ${ }^{9}$

The global rice market is a thin, segmented, and imperfect market with a limited number of buyers and sellers, with unpredictable levels and sources of demand, leading to instability and uncertainty (Roche, 1992: 1-2). There are an estimated 110 countries that produce rice, but only a few participate in the export market and only $6.3 \%$ of global rice production is traded internationally.

Ninety percent of global supply is now produced and consumed in Asia (Hossain and Narciso, 2004). Southeast Asia stands at the center of the global rice economy, contributing 39.9\% of global exports in 2016 (Omar et al., 2019: 5). Exporters include Thailand, Vietnam, India, the United States, China, Pakistan, Australia, Italy, Uruguay, Argentina., Egypt and Spain and the first five control $75 \%$ of the market (Hossain and Narciso, 2004). Among the five, Thailand controls $30 \%$ of the market (ibid.).

Critical studies about the fragility of supplies first emerged in 1992, when $98 \%$ of 354.46 million Metric Tons (MT) of global supply was consumed in their respective countries of production. Only about 12.89 million MT (3.6\%) was exported, while 12.34 million MT (3.4\%) were imported (Roche, 1992: 148).

With fragile supplies, the general tendency of rice-producing countries is to secure domestic output for their own populations and rely on imports to offset deficiencies in domestic supply. Herein lies the challenge: how can this strategy work in a market beset with uncertainty, complexity, and unbridled competition, and in a situation where global rice supplies are unreliable? 
The challenge was underlined in the 2007-2008 rice crisis when only 7\% of the 432.6 million MT global output was traded in international markets (Manzano and Prado, 2014). The corresponding price shock saw global prices rising from US $\$ 335$ to US $\$ 1,000$ per MT between April 2007 and October 2008 (ibid.). It also induced the sort of "beggar thy neighbor policies" that permitted rice to be smuggled under the gaze of national states and substates. In some provinces of the southern Philippines, smuggled rice flooded local markets with very little state intervention and interdiction. In Sabah and other parts of Malaysia, rice that was imported from Vietnam and Thailand found its way into Philippine markets.

The Philippines modified its policies on importation and allocated 200,000 MT for private sector importation from a total of 2.2 million MT imported (Briones and De la Pena, 2015). During the period, Philippine rice imports comprised $7 \%$ of the total supply traded in the international market. Meanwhile, Malaysia responded to the 2008 rice crisis with a knee-jerk reaction to increase the national stockpile threefold, from 92,000 MT to 292,000 MT, also by importation (Omar et al., 2019: 150).

Malaysia and the Philippines are net importers of rice. They belong to the top ten countries that are dependent on imports. Their 2019 rice trade deficits were worth US $\$ 441.9$ million and US $\$ 1$ billion, respectively. ${ }^{10}$ Their import partners from Southeast Asia - Thailand, Vietnam, Myanmar and Cambodia - belong to the top ten highest rice export gainers during the same year. ${ }^{11}$ Thailand alone gained US $\$ 4.2$ billion in rice export revenues during the year. ${ }^{12,}$

A perennial problem on the Philippine side is rice smuggling, with milled rice being the top agricultural product being smuggled (Lantican \& Ani, 2020). An estimated US $\$ 1.96$ billion worth of milled rice was smuggled to the country between 1986 to 2009 (Alano, 1984). The phenomenon is not completely outside the law. Lantican \& Ani (ibid.) show consistent discrepancy of exporting country reports and reports of the Philippine Bureau of Customs averaging $23.3 \%$ underreporting during the 2004-2016 period.

During the pre-election year rice crisis in 2018, the Philippine Secretary of Agriculture even proposed the "legalization of rice smugglers" to appease angry publics and recover foregone revenues in the form of "tara" (bribe money) to corrupt government officials (Business World Online, August 29, 2018). The "tara" referred to by the Secretary was generated from an estimated PHP 2 billion (roughly US $\$ 40$ million) in avoided rice import tariffs in the maritime trade between southern Philippines and Sabah during the third quarter of 2018.

The Philippines and Malaysia offer helpful comparisons in assessing the dynamics of rice supplies and how they shape smuggling behavior. Both countries are net importers of rice. Domestic output is traded in-country and supply is stabilized with strong control measures and devices. Exposure in the international rice market is mainly used to offset shortfalls in domestic supply and ensure availability of buffer stock.

We also need to change our views about the so-called illegality of rice smuggling in this porous border. Traders do not perceive their actions as illegal. When rents are paid, these payoffs land in the pockets of the same "law enforcers" or customs agents that are supposed to enforce trade laws.

There is a legal loophole that allows customs officials to look the other way. The Philippine Anti-Agricultural Smuggling Act of 2016 declares large-scale smuggling as economic sabotage or a high crime. However, it is lenient on rice smuggling while harsh on other agricultural products. A smuggler of onions, sugar, corn, pork, poultry, carrots or fish could be considered a saboteur if the Customs valuation of the intercepted goods is PHP 1 million (US\$19,700). One has to smuggle PHP 10 million worth of rice (US\$197,055), or ten times as much, to be considered a saboteur. 
Most of the traders involved are thousands of small women merchant-buyers who partake of the income and benefits to be derived from a coping or survival economy. The view that the smuggling of rice is violent and operates below the pale of the law is undermined in the porous borders of the Sulu Sea where rice smugglers often conduct their business aboveground and in an orderly and non-violent manner - under the noses of State regulators who partake of the "taxes" and "duties" paid to them. ${ }^{13}$

These factors point to a critical yet seldom acknowledged fact; i.e., that the porous maritime borders of Southeast Asia represent a de-facto free trade zone in rice.

\section{Rice smuggling in regional and historical perspectives}

The maritime border between the Philippines and Malaysia used to be a robust international "free trade zone" in the seventeenth and eighteenth centuries (Warren, 1977; Warren, 2011). Various commodities were traded, including food products and prestige goods that extended as far as Indonesia, Thailand, China, and India. Goods were not "smuggled," because no duties were expected to be paid for selling and buying rice. In fact, the unfettered traditional trade and exchange of goods across the Sulu Sea became bounded only in the post-colonial period when the legal and normative beginnings of the crime of "smuggling" became prominent between the Philippines, Sabah, and the bigger Federation of Malaya and Indonesia.

In 1967, the Philippines and Malaysia signed an anti-smuggling pact specifically to regulate trade in rice and other commodities between the Philippines and Sabah. ${ }^{14}$ The agreement provided for the placement of Philippine customs stations in Sandakan, Semporna and Kota Kinabalu and free movement of people residing in border areas. ${ }^{15}$ The protocol to the agreement defined the border areas: the Sabah administrative districts of Sandakan, Lahad Datu, Semporna, Kudat and Tawau on the Malaysian side and the Province of Sulu and the Balabac Island Group including Palawan Province on the Philippine side. ${ }^{16}$ People living in the border areas could move freely for business, social visits and pleasure with the mere carriage of a twoweek border pass and without need of a passport.

However, cooperation against smuggling dwindled less than a year the signing of the antismuggling pact. Diplomatic relations between the two countries soured in 1968 when the Philippine government passed Republic Act No. 5446 that referred to Sabah as part of Philippine territory. ${ }^{17}$

Nevertheless, the peoples of Sabah and southern Philippines continued to engage in trade and social visits. The salience of trust and the role of traditional social networks such as the Muslim clans and tribes on both sides of the maritime border, plus the free and robust movement of people and goods is manifest in the fact that cross-border trade in rice has always referred to the centuries-old practice of barter as reference.

\section{Barter as concealment of rice smuggling}

The maritime trade exchanges connecting Tawi-Tawi (Philippines) and Sabah (Malaysia) is one such arena where traditional norms governing the exchange of goods and ethnic ties were being reformed in the post-colonial period. The traditional exchange of goods was redefined as smuggling and the nurturing of ethnic ties as illegal immigration. Only the traditional and embedded practice of barter survived the changes in trade rules - remaining as a social practice that is mutually recognized by both the Philippines and Malaysia. ${ }^{18}$

The practice of barter trade is context specific and geographically situated. In Sabah, rice exports to Southern Philippines used the language of barter even when it was enabled by the 
trans-shipment of rice from Vietnam or Thailand. In short, the incoherence and inconsistency in rules governing barter trade facilitates the illicit trade in rice. The conclusion that one gets is that barter really constitutes just one of many transactions that masks the smuggling of rice into different borders. This thesis is buttressed too by the formidable requirements for regulating frontier areas governed by traditional rules and practices.

The shared maritime borders among the Philippines, Malaysia and Indonesia are two adjacent seas, the Celebes and Sulu seas, that encompass 210,000 square miles. It forms part of the global trade route. It is difficult to control not only because of its size, but also because of the thousands of ocean-going vessels plying the route. ${ }^{19}$ The eastern coast of Sabah, particularly, Sandakan, Lahad Datu, Semporna and Tawi - is a maze of coral reefs, sandbars, mudflats, shoals and submerged rocks that is more suitable for small craft of seafarers with local knowledge than large-scale amphibious operations (CIA, 1969).

Although wooden-hull trading vessels are no longer registered for import trading and permitted to cross international waters, they continue to carry rice and other commodities across the Sulu Sea from the ports of Sandakan and Tawau (in Sabah) to the Chinese pier in Bongao and other island municipalities of Tawi-Tawi. ${ }^{20}$ Upon docking, Tausug crew watch over Sama laborers climbing up and down the wooden ladders to unload sacks of rice and boxes of cigarettes, cooking oil, sugar, kari noodles and other foodstuffs to the backsides of a row of apartments that double up as bodegas (small warehouses) and wholesale stores. Most of these are owned by Chinese merchants, for whom the pier is named.

Alongside the trading vessels are passenger liners ready to load people and cargo for travel and distribution to the islands while hundreds of smaller boats carry, retail packs of rice, noodles, gasoline in family-size bottles of soft drinks, sugar, cooking oil and other stuffs for redistribution to retail stores on stilts or in the small islands nearby. On the other side of the piers are public markets where smaller stores and hawkers retail the same goods to consumers.

\section{Rice smuggling as an instituted economy $y^{21}$}

The rice economy is instituted with cultural symbols and embedded social networks and the smuggling of rice continues to be carried out using the language and practices of traditional barter traders in Sabah and Tawau in Malaysia, Tarakan in Indonesia, and Tawi-Tawi and Sulu in the southern Philippines.

Transactions include reciprocal exchanges and redistributive arrangements, i.e., prices were not solely defined by supply and demand, and arrangements allowed discounts for the poor, the disabled, victims of natural and man-made calamities, and others. Barter trade helped to thicken social capital relations and nurture kinship ties across the seas. It helped establish life-long relationships especially between women traders who were unified by one religion despite their different nationalities and tribes. This agreement held the strongest traction in the case of rice.

For example, the 40-member Karandahan Association of Tawi-Tawi is a group of Sama small traders who are directly involved in the import and retail of rice, oil, fuel, flour and sugar. Their ethnic configuration is designed to secure economic space for the Sama without clashing with the interests of big Tausug and Chinese traders. They helped lubricate the kinship relations of members with those in Sabah and Indonesia without completely isolating themselves from the wider economic field.

Working more broadly with other economic actors motivated Karandahan to become part of the Filipino Muslim Traders Association and the wider and multi-ethnic BIZNET of the Tawi-Tawi Chamber of Commerce and Industry. The wider network enabled them to identity export markets in Sabah and Indonesia. A similar dynamic occurred across the sea in Sabah 
where the traditional Tausug, Sama and Sabahan traders joined the formal groupings and institutions registered with the Sabah State Ministry of Finance.

Many people from Sulu had relatives living and working in Sabah and other adjacent Malaysian and Indonesian provinces and vice-versa. Inter-marriages among Malaysians, Filipinos, and Indonesians were not uncommon, especially among merchants and traders. Kinship ties and traditions among the Tausug, Sama, and Bajau took root amidst the shared religion and practices of Islam, and especially in the pursuit of customs, celebrations, and festivals that were woven into the trade relationships that bound residents of multiple outposts.

It was clear that the artificial territorial limitations that were imposed following the formation of modern states modified the nature of traditional trading but did not end it. The effort to divide ethnic peoples into different nationalities did not likewise deter traditional links and relationships (Chouvy, 2013: 8, 10, 11).

When Sabah was still part of the Sulu Sultanate, the Tausug and Sama Bajau who crisscrossed the Sulu Sea to barter or engage in various exchange of goods and the maintenance of social and ethnic ties did not consider themselves either Filipinos or Malaysians. Even today, the Bajau, largest ethnic group in Sabah, and the Sama Bajau of Southern Philippines pay no heed to the notion of national borders (Rabasa and Chalk, 2012: 1, 2).

We can better understand the dynamics behind the legal and illegal cross-border trade in rice that is nested in practices and traditions by travelling from Tawi-Tawi to Sabah and back.

\section{Tawi-Tawi to Sabah and back: the cross-border trade in rice}

The smuggling of rice between Malaysia and southern Philippines is a mix of small-scale procurements of rice and other foodstuffs from Sabah by barter traders from Tawi-Tawi and Sulu and large-scale rice smuggling by Manila-based big firms. Like the Philippines, the prominent role of Malaysia in rice exporting, despite the shared lack of rice surpluses is cause for serious attention. Both countries appear to function as the providers of international free ports and trans-shipment facilities that bigtime smugglers can use for their Southeast Asian rice trading operations.

Traveling in the Sulu Sea to scope the legal and illegal transit of rice and other commodities gives any observer a front-row seat into the intricacies of the rice trade and an insight into the sophistication of its participants, especially the women-merchant traders coming from all the ports across the Sulu Sea.

Behind the surge of large-scale smuggling and away from the headlines of news dailies is the regularity of cross-border trading between Tawi-Tawi and Sabah. While Zamboanga City serves as a conduit for large-scale smuggling and redistribution to the national capital, Bongao, the capital of Tawi-Tawi, serves as the nexus for the redistribution of smuggled rice into the islands, including those Malaysian islands close to Tawi-Tawi.

Tawi-Tawi traders procure rice from registered barter traders in Sabah and procure supplies from the ports of Sandakan and Tawau. The smuggled rice is then brought to Bongao, which is the locus of a highly organized smuggling supply chain. From Bongao, rice is procured by merchant-traders, many of whom are women entrepreneurs who pool their capital to buy in the barter trade markets for immediate redistribution to local consumers. This system is different from that of large-scale smugglers using the same transhipment node, transferring the smuggled rice to private wharfs and warehouses in Zamboanga City before re-transporting them to large markets in the National Capital Region.

Rice is brought to Tawi-Tawi, not hidden in containers nor mixed with other goods; it is out in the open or brought in with fake invoices. Everyone knows that the legal documents are 
flawed and that the data on rice volumes and prices are all faked, but everyone joins in performing a charade where people know each other, yet engage each other as if they were strangers in serious negotiation with state officials. The entire scene looked serious enough to secure a sense of formality, but in the end, you knew that each one has done this regularly, like buying and selling rice and other food stuffs next door, as they had done for centuries. Some traders sign the Informal Import Declaration and Entry Form ${ }^{22}$ and pay nominal fees while most others do not. No government agency in Tawi-Tawi is monitoring the volume and value of rice imports.

Cross-border rice trading between Sabah and Tawi-Tawi is really about the importation of rice from Sabah, and the export of a few commodities from the Philippines. Other commodities, such as copra, seaweed and fishes are rarely on the list because both ports produce ample supplies of each. Although both are deficient in rice production, Sabah is a beneficiary of leaked trans-shipped rice from Vietnam and Thailand, which in turn is re-exported and smuggled into the Philippines. ${ }^{23}$

As has been in the past, rice insufficiency is a key driver in the cross-border importation to Tawi-Tawi. The nearest and most practical source is Sabah. A trialogue with three smugglers and a discussion with other traders revealed that there were at least 300 wooden-hull vessels operating in the Zamboanga, Sulu and Tawi-Tawi areas. ${ }^{24}$ Currently, there are 15 trading vessels operating from Bongao, the capital town of the province that are owned by traders who acquired knowledge and expertise from their parents and the parents before them. ${ }^{25}$ The vessel count does not include wooden-hull vessels of lower tonnage that ferry passengers and cargoes of dried seaweed and dried fish between islands.

Wooden-hull boats from Bongao are engaged in passenger line operations to major islands of the province and tramp line freight operations in cross-border trade with Sabah. ${ }^{26}$ Tradersshippers from Bongao enter into contractual agreement with barter traders-suppliers in Sabah. Before the Malaysian ban on rice transhipment in late 2018, a hundred boats take off from Sabah each month, exporting rice worth RM 600,000 (roughly, US\$140,000) and other supplies such as sugar, flour and cigarettes worth RM 300,000 (roughly US $\$ 70,000$ ) per boat (Borneo Post, January 6, 2019). ${ }^{27}$ Bongao traders usually mobilize PHP 10 to 12 million of capital (roughly, US\$200,000-240,000) for each trading run of break-bulk cargo consisting of rice, noodles, cooking oil, cigarettes and other stuffs.

Cross-border trading is a pooled endeavor involving the vessel owner and his crew, plus the politicians, policemen, teachers, entrepreneurs, and other stakeholders that are either on board the vessel or invested heavily in its cargo. Capital is raised among interested parties who can put up at least PHP 40,000 to PHP 50,000 per trip, for a total of at least PHP3-5 million per trip. Purchase capital is electronically transmitted in advance by pawnshops doubling as remittance centers in Bongao in close coordination with remittance centers in Sabah.

The entire enterprise relies on high levels of trust - in the safety of the vessel, the protection of its passengers, and the guaranteed return on investments. Actual trading is highly capitalized and the risks are shared by everyone on board, in varying scales, according to each one's capacity and resources. Passengers on the vessel are joined by rice resellers in wholesale markets, other small boat owners, and a few port loaders.

All smuggled goods are declared as "barter" goods. In addition to bulk cargo on woodenhulled freight vessels, small-scale smuggled goods are brought back by passengers on liner vessels or by small traders from outlying islands nearest to Sabah such as Sitangkai and Sibutu (closest to Semporna, Lahad Datu and Tawau) or Cagayan de Sulu (closest to Sandakan). Landed costs and domestic retail prices are low because of avoided tariffs while boat owners and trip organizers shield the "investors" from administrative costs and rents accruing to customs officials. 
The entire trip is a chance to witness the longstanding ethnic ties between the Bajaus, largest ethnic group in Sabah, and the Sama Bajau of the Southern Philippines who both pay little heed to national borders. According to a Sama Bajau trader interviewed on board the vessel, the Sama Bajau in the eastern parts of Indonesia, Eastern Sabah and Southern Philippines are really engrossed with rice because it is seen as the most important agricultural crop. ${ }^{28}$ Buwas kuning (yellow rice ${ }^{29}$ ) is an indispensable part of the pag-omboh (giving food to dead ancestors) and magomboh (annual rice ritual), which are mandatory and believed to be the means of protecting families from curses (Hussin, 2019). The preparation of buwas kuning itself is socially significant and is often accompanied by deeds of sharing and family reunions.

It was also a chance to recognize the unifying force of a single religious identity in the dominant Islamic religion of citizens in both Tawi-Tawi and Sabah. Like other Muslims, the abject conditions brought by natural or man-made calamities, where the hoarding of goods and the monopoly of scarce resources is a kneejerk response, was universally scorned by all the respondents aboard the ship. They claimed that the admonitions in the Qu'ran and the Hadith prevented that kind of behavior. They are jovial and generous and each one partakes of one another's food.

There is indeed some symmetry in the practices of Asian peoples where rice is not only a cereal for basic sustenance but is also woven into social, religious, and cultural fabric of life. In one conversation the author heard of the many different ways to cook and process rice, including the rituals and festivals that accompanied these processes. Rice also played a prominent role in marriage ceremonies in both Sabah and Tawi-Tawi. Finally, for the Ibans of Sarawak, rice is central to their ancestors, and the author was fortunate to have joined a weeklong rice festival when communities from other Rumahs joined the celebration.

\section{Conclusion}

The smuggling of rice persists despite continued efforts to strengthen regulation and crosscountry cooperation in monitoring and policing the porous borders of the Sulu Sea, because of the convergence of economic and social incentives and motivations among those involved in smuggling - whether as perpetrators or regulators. Rice smuggling, as we have seen, is community driven and founded upon a long-standing tradition of barter trade and reciprocal food security, ring-fenced from criminal activity and contributive to political and economic stability.

Rice smuggling is not only an informal economy, but also an economic arrangement that straddles different sets of institutions: legal and illegal; formal and informal; aboveground and underground. Across the porous borders of Southeast Asia where rice is traded, we see actors wearing different hats - as enforcers and facilitators or as formal and shadow authorities who possess legitimacy and authority.

Illicit cross-border trade of rice and other goods between the Tawi-Tawi, Philippines and Sabah, Malaysia has persisted because it is protected from coercive strategies by multiple layers of stakeholders that benefit from the trade. They include the extended families, clans, and tribes that are settled in the various ports across the Sulu Sea, the women trader-entrepreneurs who travel regularly to Sabah and vice-versa to buy supplies that they can sell, the shadowy authorities involved in the importation and exportation of other illicit goods that can be shipped and disguised as rice shipments, the formal authorities who collect the rents in numerous tollgates, and the armed groups and terror networks, engaged in kidnap-for-ransom and human trafficking, that are able to wreak havoc in this loosely monitored and unguarded part of Southeast Asia. 
Finally, there are the traders themselves who want to prevent the same racist idioms and targeted attacks waged by various publics against their families and enterprises in times of rice scarcity and price instability. Food rioting is a frightening experience that has occurred in both Indonesia and Malaysia, and the attacks and looting of granaries are a particular phenomenon in the Philippines. In all these cases, the indigenous Chinese traders have borne the brunt of attacks on their lives and properties.

This continued smuggling of rice is anchored on a paradox: it is a staple food in Malaysia and the Philippines. While both countries have an incentive to ensure stable supplies and the absence of severe price fluctuations, the same rice smuggling can lead to prices that can disrupt incentives for producers in both countries to produce rice sufficiently. This interaction will create perpetual tensions and place both the state and social forces into situations where they will alternately collide or cooperate to avoid a prolonged food crisis where "rice nationalism" may emerge and threaten food security over the long term.

This chapter presented counter-intuitive findings that broke some myths about how this informal economy is viewed. The social networks that operate beneath the radar to sustain smuggling activities underscore the rule-systems that people find important in an economy embedded in their traditions and social relations.

We have seen how food security is a legitimate social aspiration that cannot be barred by restrictions, legal or otherwise. It is crucial for the legitimacy, authority, and the longevity of an existing regime, and will remain an overarching objective that needs to be fulfilled.

We have also seen the impervious nature of the barter system as the language of compromise between rice smugglers and legal authorities on both sides of the Sulu Sea. When barter is evoked, everything falls in place - the tolerance, the higgling and haggling, the settlement, and finally, the payments that illustrate the huge revenues that are lost from government coffers. Because of this institutionalized process, the BIMP-EAGA aim to formalize the barter trade will not work. ${ }^{30}$

In conclusion, it is important to emphasize that the reigning frameworks used in the conduct of informal economy studies must shift from the formal-informal and legal-illegal dichotomies into a new framework that illustrates and reveals the seamlessness between two systems that interact regularly. Rice smuggling is, after all, an economic, social, and political arrangement that straddles different sets of institutions: legal and illegal; formal and informal; and aboveground and underground.

\section{Notes}

1 The Sulu and Celebes seas are on the southern tip of the Philippines flanking the Sulu Archipelago on the southwest and southeast. Both seas were the sites of the seventeenth-eighteenth-century robust international trade in what Warren $(1977,2011)$ called the Sulu Zone. They served as borderless maritime bridges among peoples in the Celebes islands, coastal zones of North Borneo and Sulu Archipelago, engendering evolution of economic, social and political institutions until disrupted by the colonial projects of the Dutch and Portuguese in Indonesia, the British in North Borneo and the Spanish and Americans in the Philippines. Henceforward, new borders were created during the formation of the Malaysian, Indonesian and Philippine states after World War II.

2 Donnan and Wilson (199) argue that smuggling is an act of subversion that defy borders and, therefore, the state.

3 Literature specific to rice smuggling is scarce. Bonnier and Bonnier (2019) cite that organized crime plays a major role in the illicit trade of agri-food products (in general) and that the same trade destabilizes food security, subsidizes wider criminal activity and threaten political and economic stability.

4 Centeno and Portes (2006) argue that the relationship between the state and informal economy actors is theoretically and inevitably conflictive given state assertion of monopoly of authority and, on the 
other, propensity of informal economy actors to subvert that authority. However, within that antithesis of state power and informality is the practical devolution of such conflict into various forms of accommodation.

5 Trialogues are mediated dialogues where a third-party participates in an in-depth interview or conversation to build trust and mediate the discussion of delicate and controversial issues that may surface. These are often used in interview sessions where the presence of a third-party trusted by the respondent enables the sharing of confidential information.

6 The kumpit is a seagoing trading vessel that can carry about 500 metric tons of rice and other commodities across the Sulu Sea to various ports in Malaysia and Indonesia.

7 The move echoes the anti-Chinese riots in 1965 when the Indonesian military accused ethnic Chinese as the fifth column of the Chinese Communist Party (Indonesia Alert, ibid.).

8 It is estimated that 1600-2000 people were killed and 15,000 arrested during the violent response of the Zia ul-Haq regime in 1986 (Mukherjee and Koren, 2019).

9 See Hurrell (2003). International Law and the Making and Unmaking of Boundaries, in Moore, M. and A. Buchanan. (eds.). (2003). States, Nations and Borders: The Ethics of Making Boundaries. Cambridge, UK: Cambridge University Press, p, 287.

10 See: http://www.worldstopexports.com/rice-exports-country/

11 Ibid.

12 Ibid.

13 In her study on smuggling along the border of Cameroon and Nigeria, Niger-Thomas (2001) found that women traders perceived their activities as legitimate even though they recognized that they were still taking risks.

14 Agreement on anti-smuggling cooperation between the government of Malaysia and the government of the Republic of the Philippines, September 1, 1967; from https://www.officialgazette.gov.ph/1967/09/ 01/the-philippine-claim-to-a-portion-of-north-borneo-agreement-on-anti-smuggling-cooperation-between-the-government-of-malaysia-and-the-government-of-the-republic-of-the-philippines/.

15 Ibid.

16 Protocol to the agreement on anti-smuggling cooperation between the government of Malaysia and the government of the Republic of the Philippines; from https://www.officialgazette.gov.ph/1967/ 09/01/the-philippine-claim-to-a-portion-of-north-borneo-protocol-to-the-agreement-on-antismuggling-cooperation-between-the-government-of-malaysia-and-the-government-of-the-republicof-the-philippines/.

17 REPUBliC ACT NO. 5446, An Act to Amend Section One of Republic Act 1346, entitled: "An Act to define the Baselines of the Territorial Sea of the Philippines". From: https:// www.officialgazette.gov.ph/1968/09/18/republic-act-no-5446/.

18 Barter is very similar to what Bevan \& Wengrow (2010:22) described as a bazaar economy where transactions involve mobilization of personal networks of loyalty and affiliation.

19 See: Rabasa, A. and Chalk, P. (2012). Non-Traditional Threats and Maritime Domain Awareness in the Tri-border Area of Southeast Asia: The Coast Watch System of the Philippines. Sta. Monica, CA: Rand Corporation. https://www.rand.org/content/dam/rand/pubs/occasional_papers/2012/RAND_ OP372.pdf. From December 2010 to July 2011, 55,368 vessels were monitored.

20 Under Philippine Maritime Industry rules (MARINA Memorandum Circular No. 73, series of 1993), wooden-hull vessels below 500 Gross Registered Tons may be given Temporary Special Permit on condition that owners also procure Manning Certificate, Cargo Ship Safety Equipment Certificate, Radio Station License and International Loadline Certificate (Maritime Industry Authority, 1993). The Maritime Industry Authority has, since 2007, suspended registration of newly acquired and newly built wooden-hulled ships. All ships plying overseas should be made of steel (Maritime Industry Authority, 2007).

21 An instituted economy according to Polanyi $(1944 / 1957,60,62,64)$ refers to the human economy as an instituted process, embedded and enmeshed in institutions or rules that may be economic or noneconomic. Rice is an instituted economy because it is an enterprise embedded in more than just simple market exchanges, but also norms, motives, and values.

22 This is the Bureau of Customs (BOC) Import Entry and Import Declaration and Entry Form 177 for barter traders. They cannot sign BOC Form 236 (Import Entry and Internal Revenue Declaration Form) because this form is only for registered steel-hulled vessels.

23 In the aftermath of Philippine interception of smuggled rice from Sabah in June 2018, the Malaysian Ministry of Agriculture and Agri-based Industry banned transhipment in July 2018. The ban has been 
extended since January 1, 2019 (http://www.olgn.org/wp-content/uploads/2018/12/7.-OL-USAindustry-news.pdf). In a statement to the Malaysian Parliament on 19 March 2020, Chan Foong Hin (MP for Kota Kinabalu) called for the lifting of the ban on the ground that not all rice transhipment involves smuggling ("No to total ban of rice transhipment in Sabah," https://dapmalaysia.org/statements/2 019/03/19/28383/). Earlier the BIMP-EAGA Business Council also lobbied for the lifting of the ban (https://www.thestar.com.my/news/nation/2018/08/13/council-lift-rice-transhipment-ban/).

24 See Nikko Fabian, "Plea to allow Kumpits when barter trade resumes," Daily Express, July 21, 2019. Retrieved from: http://www.dailyexpress.com.my/news/138163/plea-to-allow-kumpits-whenbarter-resumes/.

25 Interview with a local trader based in Bongao, Tawi-Tawi (17 June 2020). Name and location withheld.

26 See Austria, M. (2002). Philippine Domestic Shipping Industry: State of Competition and Market Structure, PASCN Discussion Paper No. 2002-04. Philippine Institute for Development Studies, Makati City. http://pascn.pids.gov.ph/DiscList/d02/s02-04.pdf. The domestic shipping transport industry consists of three sectors: liner, tramp and industrial carriage. New regulations prescribe that vessels used for international shipping should be steel-hulled, among other requirements.

27 Roughly US $\$ 138,000$ or PHP 6.9 million worth of rice based on US $\$$ to RM and US $\$$ to PHP exchange rate on 22 March 2020.

28 Name and date withheld.

29 White rice becomes yellow rice when mixed with dulaw (turmeric) during cooking. The practice is also common among Maranaw and Maguindanao Muslims in the Philippines.

30 BIMP-EAGA stands for Brunei Darussalam-Indonesia-Malaysia-Philippines, an ASEAN sub-regional cooperation system that started in 1994 and encompasses the whole of Brunei Darussalam, the provinces of Kalimantan, Sulawesi, Maluku and West Papua in Indonesia, the states of Sabah, Sarawak and federal territory of Labuan in Malaysia and Mindanao and the province of Palawan in the Philippines. One of the agendas of the sub-regional cooperation system is the revival and formalization of barter trade.

\section{Bibliography}

Abraham, I. and van Schendel, W. eds., (2005). Introduction: The Making of Illicitness. In: Illicit Flows and Criminal Things: States, Borders and the Other Side of Globalization. Bloomington and Indianapolis: Indiana University Press, pp. 1-37.

Ahuja, S.C. and Ahuja, U. (2010). Rice in Social and Cultural Life of People. In Sharma, S.D. (ed.). Rice: Origin, Antiquity and History. Boca Raton, FL: CRC Press, pp. 39-84.

Alano, B. (1984). Import Smuggling in the Philippines, An Economic Analysis, Journal of Philippine Development, Volume XI, Issue 2, Philippine Institute of Development Studies. Available at: https:// dirp4.pids.gov.ph/ris/pjd/pidsjpd84-2smuggling.pdf (Accessed: 16 January 2021).

Amirell, S. E. (2005). The Return to Piracy: Decolonization and International Relations in a Maritime Border Region (the Sulu Sea), 1959-63, Working Papers in Contemporary Asian Studies no. 15, Center for East and South-East Asian Studies, Lund University. Available at: http://portal.research.lu.se/ws/ files/4564544/3127790.pdf (Accessed 27 April 2018).

Balisacan, A., Sombilla, M. and Dikitanan, R. (2010). Rice Crisis in the Philippines: Why Did It Occur and What Are Its Policy Implications?, In Dawe, D. (ed.). The Rice Crisis Markets, Policies and Food Security. London and Washington: Earthscan and FAO.

Bevan, A. and Wengrow, D., eds., (2010). Cultures of Commodity Branding. First Edition. Left Coast Press: Left Coast Press.

Bhagwati, J. and Hansen, B. (1973). A Theoretical Analysis of Smuggling, The Quarterly Journal of Economics, Volume 87, Issue 2, pp. 172-187. Available at: 10.2307/1882182 (Accessed: 27 April 2021).

Bonnier, U. and Bonnier, L. (2019). Mapping the Impact of Illicit Trade on the Sustainable Development Goals. Transnational Alliance to Combat Illicit Trade (TRACIT). [ebook]. Available at: https://unctad.org/ meetings/en/Contribution/DITC2019_TRACIT_IllicitTradeandSDGs_fullreport_en.pdf (Accessed: 28 December 2020).

Briones, R. and De la Pena, B. (2015). Competition Reform in the Philippine Rice Sector, Discussion Paper Series No. 2015-04, Philippine Institute of Development Studies. Available at: https:// pidswebs.pids.gov.ph/CDN/PUBLICATIONS/pidsdps1504.pdf (Accessed: 27 December 2020). 
Castells, M. and Portes, A. eds., (1989). World Underneath: The Origins, Dynamics and Effects of the Informal Economy. In: The Informal Economy: Studies in Advanced and Less Developed Countries. Baltimore and London: The Johns Hopkins University Press, pp. 11-37.

Centeno, M. A. and Portes, A. eds., (2006). The Informal Economy in the Shadow of the State. In: Out of the Shadows: Political Action and Informal Economy in Latin America. University Park, PA: The Pennsylvania State University Press, pp. 23-48.

Chouvy, P. A. ed., (2013). An Atlas of Trafficking in Southeast Asia: The Illegal Trade in Arms, Drugs, People, Counterfeit Goods and Natural Resources in Mainland Southeast Asia. New York, NY: I.B. T Co. Ltd.

Chen, M. A. ed., (2006). Rethinking the Informal Economy: Linkages with the Formal Economy and the Formal Regulatory Environment. In: Linking the Formal and Informal Economy: Concepts and Policies. Oxford, UK: Oxford University Press, pp. 75-92.

CIA. (1969). Intelligence Report: Geographic Brief on Sabah. Available at: https://www.cia.gov/library/ readingroom/docs/CIA-RDP84-00825R000100620001-7.pdf (Accessed: 15 December 2020).

Cororaton, C. (2004). Rice Reforms and Poverty in the Philippines: A CGE Analysis, ADB Institute Discussion Paper No.8. Available at: https://www.adb.org/sites/default/files/publication/156759/ adbi-dp8.pdf (Accessed: 16 December 2020).

Customs Administrative Order No. 13-2019, Customs Bonded Warehouses. Available at: https://customs.gov.ph/wpcontent/uploads/2019/10/cao-13-2019-Customs_Bonded_Warehouses.pdf (Accessed: 24 January 2021).

De la Rosa, N.P. (2014). Porous Peace in Mindanao's Free Trade Area, Policy Brief, April 2014, International Alert. Available at: https://www.international-alert.org/sites/default/files/Philippines_ PolicyBriefBorderTrade_EN_2014.pdf (Accessed: 13 December 2020).

Granovetter, M. (1985). Economic Action and Social Structure: The Problem of Embeddedness. American Journal of Sociology, Volume 91, Issue 3, pp. 481-510.

Granovetter, M. (2017). Society and Economy: Framework and Principles. Cambridge, Massachusetts: The Belknap Press of Harvard University Press.

Hedman, E. and Sidel, J. (2000). Philippine Politics and Society in the Twentieth Century: Colonial Legacies, Post-Colonial Trajectories. London and New York: Routledge.

Hossain, M. and Narciso, J. (2004). Global Rice Economy: Long-Term Perspectives. In: FAO Conference Rice in Global Markets and Sustainable Production Systems. Roe. Available at: http://www.fao.org/rice2 004/en/pdf/hossain.pdf (Accessed: 13 December 2020).

Hurrell, A. (2003). International Law and the Making and Unmaking of Boundaries. In: Moore, M. and Buchanan, A., eds. (2003). States, Nations and Borders: The Ethics of Making Boundaries. Cambridge, UK: Cambridge University Press.

Hussin, H. (2019). Buwas Kuning (Yellow Rice) and Its Symbolic Functions among Bajaus of Malaysia. SAGE Open. Available at: https://journals.sagepub.com/doi/full/10.1177/2158244019885140 (Accessed: 13 December 2020).

Indonesia Alert, Economic Crisis Leads to Scapegoating of Ethnic Chinese, February 18, 1998. Available at: https://www.hrw.org/report/1998/02/18/indonesia-alert/economic-crisis-leads-scapegoating-ethnic-chinese-february-1998

Intal, P. and Garcia, M. (2008). Rice and Philippine Politics. Research Paper Series RPS 2008-01, Philippine Institute for Development Studies. Available at: https://pidswebs.pids.gov.ph/CDN/ PUBLICATIONS/PIDSRP0801.pdf (Accessed: 17 December 2020).

International Alert. (2014). Rebellion, Political Violence and Shadow Crimes in the Bangsamoro: The Bangsamoro Conflict Monitoring System (BCMS) 2011-2013. [ebook]. Available at: https://www.internationalalert.org/sites/default/files/Philippines_BangsamoroConflictMonitoringSystem_EN_2014.pdf (Accessed: 21 December 2020).

International Alert-Philippines. (2016). Violence in the Bangsamoro and Southern Mindanao 2011-2015. [ebook]. Available at: https://conflictalert.info/publication/ (Accessed: 21 January 2020).

Lantican, T.L.D.C. and Ani, P.A. (2020). The Philippine Fight against Agricultural Smuggling: Review of Philippine Policies and Initiatives. [ebook] FFTC Agricultural Policy Platform. Available at: https:// ap.fftc.org.tw/article/1867 (Accessed: 16 February 2021).

Manzano, G. and Prado, S.A. (2014). Distributional Impact of the 2008 rice crisis in the Philippines. [ebook]. Available at: https://unctad.org/en/PublicationChapters/gds2014d3_02_Philippines_en.pdf (Accessed: 12 February 2021).

Maritime Industry Authority Memorandum Circular No. 73-1993, Guidelines on the Temporary Utilization of Inter-island/Coastwise Vessels in the Overseas/Trade Operations, including Barter Trade. Available at: https://marina.gov.ph/wp-content/uploads/2018/07/mc073.pdf (Accessed: 2 February 2021). 
Maritime Industry Authority Advisory No. 02-2007, Prohibition of the Registration of Newly-acquired/Built Wooden Hulled Ships. Available at: https://marina.gov.ph/wp-content/uploads/2018/07/MA-200702.pdf (Accessed: 2 February 2021).

Mukherjee, B. and Koren, O. (2019). The Politics of Mass Killing in Autocratic Regimes. Cham, Switzerland: Palgrave Macmillan.

Niger-Thomas, M. (2001). Women and the Arts of Smuggling. African Studies Review, Volume 44, pp. 43-70.

OECD/ILO (2019). Tackling Vulnerability in the Informal Economy, Development Centre Studies. [ebook] Paris: OECD Publishing. Available at: 10.1787/939b7bcd-en (Accessed: 22 January 2021).

Omar, S.C., Shaharudin, A. and Tumin, S.A. (2019). The Status of the Paddy and Rice Industry in Malaysia. [ebook] Kuala Lumpur: Khazanah Research Institute. Available at: http://www.krinstitute.org/ assets/contentMS/img/template/editor/20190409_RiceReport_Full\%20Report_Final.pdf (Accessed: 16 January 2021).

Polanyi, K. (1957). The Economy as Instituted Process. In: Polanyi, K. Arensberg, C. and Pearson, H., eds. (1957). Trade and Market in the Early Empires, New York: The Free Press.

Polanyi, K. (1944/1957). The Great Transformation: The Political and Economic Origins of Our Time. Boston: Beacon Press.

Portes, A. (2010). Economic Sociology: A Systematic Inquiry. Princeton, NJ: Princeton University Press.

Rabasa, A. and Chalk, P. (2012). Non-Traditional Threats and Maritime Domain Awareness in the Tri-border Area of Southeast Asia: The Coast Watch System of the Philippines. [ebook] Rand Corporation. Available at: https://www.rand.org/content/dam/rand/pubs/occasional_papers/2012/RAND_OP372.pdf (Accessed: 13 December 2020).

Roche, J. (1992). The International Rice Trade. Cambridge, England: Woodhead Publishing Limited.

Saleeby, N. (1908). The History of Sulu. Manila: Bureau of Printing.

Samad, P.A. and Darusalam, A.B. (1992). Malaysia-Philippines Relations: The Issue of Sabah, Asian Survey. Volume 32, Issue 6, pp. 554-567. Available at: 10.2307/2645160 (Accessed: 25 January 2021).

Sarris, A. (2010). Trade Related Policies to Ensure Food (Rice) Security in Asia. In: Dawe, D., ed. (2010). The Rice Crisis: Markets, Policies and Food Security. London and Washington, DC: Earthscan and FAO, pp. 61-87.

Tagliacozzo, Eric. A Sino-Southeast Asian Circuit: Ethnohistories of the Marine Goods Trade. In: Tagliacozzo, E. and Chang, W., eds. (2011). Chinese Circulations: Capital, Commodities, and Networks in Southeast Asia. Durham and London: Duke University Press, pp. 432-454.

The Asia Foundation (2019). Trade in the Sulu Archipelago: Informal Economies Amidst Maritime Security Challenges. [ebook] San Francisco: The Asia Foundation. Available at: https://asiafoundation.org/wpcontent/uploads/2019/10/Trade-in-the-Sulu-Archipelago-Informal-Economies-Amidst-MaritimeSecurity-Challenges.pdf (Accessed: 20 January 2021).

Timmer, P. (2010). Food Security in Asia and the Challenging Role of Rice. The Asia Foundation, Occasional Paper No. 4. Available at: https://www.asiafoundation.org/resources/pdfs/OccasionalPaperNo4Food SecurityFinal.pdf (Accessed: 18 December 2020).

Trocki, C. (1979). Prince of the Pirates: The Temenggongs and the Development of Johor and Singapore, 1784-1885. Singapore: Singapore University Press.

Trocki, C. (1990). Opium and Empire. Ithaca, NY: Cornell University Press.

United States Department of State. (2016). Country Reports on Terrorism 2015 - Foreign Terrorist Organizations: Abu Sayyaf Group. Available at: https://www.refworld.org/docid/57518d6f2e.html (Accessed: 1 August 2020).

Van Schendel, W. (2005). Spaces of Engagement: How Borderlands, Illegal Flows and Territorial States Interlock. In: Van Schendel, W. and Abraham I., eds. (2005). Illicit Flows and Criminal Things: States, Borders and the Other Side of Globalization. Bloomington and Indianapolis: Indiana University Press, pp. 38-68.

Van Schendel, W. and Abraham O., eds. (2005). Illicit Flows and Criminal Things: States, Borders and the Other Side of Globalization. Bloomington and Indianapolis: Indiana University Press.

Warren, J. (1977). Sino-Sulu Trade in the Late Eighteenth and Nineteenth Century. Philippine Studies, Volume 25, pp. 50-79.

Warren, J. (2011). The Global Economy and the Sulu Zone: Connections, Commodities and Culture. Crossroads: Studies on the History of Exchange Relations in the East Asian World, Volume 3, pp. 1-38. 